\title{
Fram Strait sea-ice sediment provinces based on silt and clay compositions identify Siberian Kara and Laptev seas as main source regions
}

\author{
Dirk Dethleff ${ }^{1} \&$ Gesa Kuhlmann ${ }^{2}$ \\ 1 Institute for Polar Ecology, University of Kiel, Wischhofstraße 1-3, DE-24148, Kiel, Germany \\ 2 GFZ German Research Center for Geosciences, Potsdam, Telegrafenberg, DE-14473, Potsdam, Germany
}

\author{
Keywords \\ Fram Strait; ice sediment entrainment; Kara \\ and Laptev seas; sea-ice sediment flux; \\ sea-ice sediment provinces; shelf source \\ deposits.
}

\section{Correspondence \\ Dirk Dethleff, Institute for Polar Ecology, University of Kiel, Wischhofstraße 1-3, DE-24148, Kiel, Germany. E-mail: ddethleff@ipoe.uni-kiel.de}

doi:10.1111/j.1751-8369.2010.00149.x

\begin{abstract}
Fram Strait sea-ice sediments (SIS) contain on average more than $94 \%$ silt and clay. Both fractions were compared with bottom deposits of the Kara and Laptev seas to identify shelf sources of fine-grained Arctic SIS. Based on silt granulometry and clay mineral assemblages we determined Fram Strait SIS provinces. Western Fram Strait SIS has medium to fine silt compositions, whereas eastern Fram Strait SIS is enriched in fine silt. Western Fram Strait SIS clays (low smectite/high illite) were statistically grouped with eastern Laptev shelf deposits, and are similar to East Siberian and North American shelf sources. Eastern Fram Strait SIS clays (high smectite/low illite) cluster with shelf deposits of the western Laptev Sea and the Kara Sea. We conclude that western Fram Strait pack ice consisted of a mixture of floes from the Laptev Sea and sources farther to the east during the 1997 and 1999 sampling periods. Eastern Fram Strait ice originated from sources towards the Kara Sea. There was an average annual flux of ca. $158 \mathrm{Tg}$ (Mt) SIS export through Fram Strait during the late 1990s. We expect no qualitative changes in the SIS entrainment process ("suspension freezing") with decreasing Arctic ice cover, although the process may increase through larger fetch. SIS incorporation and flux will be enhanced with increasing shelf open water during winter freezing, and with the current acceleration of the Transpolar Drift, but we speculate that the transport of SIS towards Fram Strait will be seasonally truncated with the onset of ice-free summers in the Arctic Ocean.
\end{abstract}

Although the Arctic sea-ice cover is dramatically retreating (Rothrock \& Zhang 2005; Stroeve et al. 2005; Nghiem et al. 2007; Overland et al. 2008), the role of Arctic pack ice as a geological agent for the transport of sea-ice sediments (SIS) is still important (Darby 2003; Dethleff 2005; Eicken et al. 2005). At present, significant late summer retreat of Arctic sea ice can be observed on the shallow Siberian and Western Arctic shelf seas (Fig. 1), where processes of sediment entrainment into newly forming ice are most effective during the autumn freeze-up period and in winter polynyas at water depths shallower than 50 m (Reimnitz et al. 1993; Eicken et al. 2000; Dethleff \& Kempema 2007). The extreme summer ice retreat increasingly provides shallow shelf areas now available for SIS entrainment during autumn and winter, which were formerly covered by pack ice year round.
Sea-ice sediment entrainment occurs during late autumn and winter in shallow, ice-free shelf areas (autumn open water and polynyas). In the process of suspension freezing, turbulent mixing of the water column leads to the incorporation of shelf sediments into new ice (Campbell \& Collin 1958; Reimnitz et al. 1992; Dethleff \& Kuhlmann 2009). Suspension freezing is driven by turbulent mixing that brings frazil and suspended sediment into contact in the water column, where they form buoyant, sediment-laden flocs that are incorporated into the newly forming ice cover. Anchorice formation may also play a role in SIS entrainment (Reimnitz et al. 1993).

Minimum concentrations of Arctic SIS are generally a few mg per litre, whereas turbid sea ice mostly contains about $50-500 \mathrm{mg} \mathrm{l}^{-1}$, with maximum concentrations 


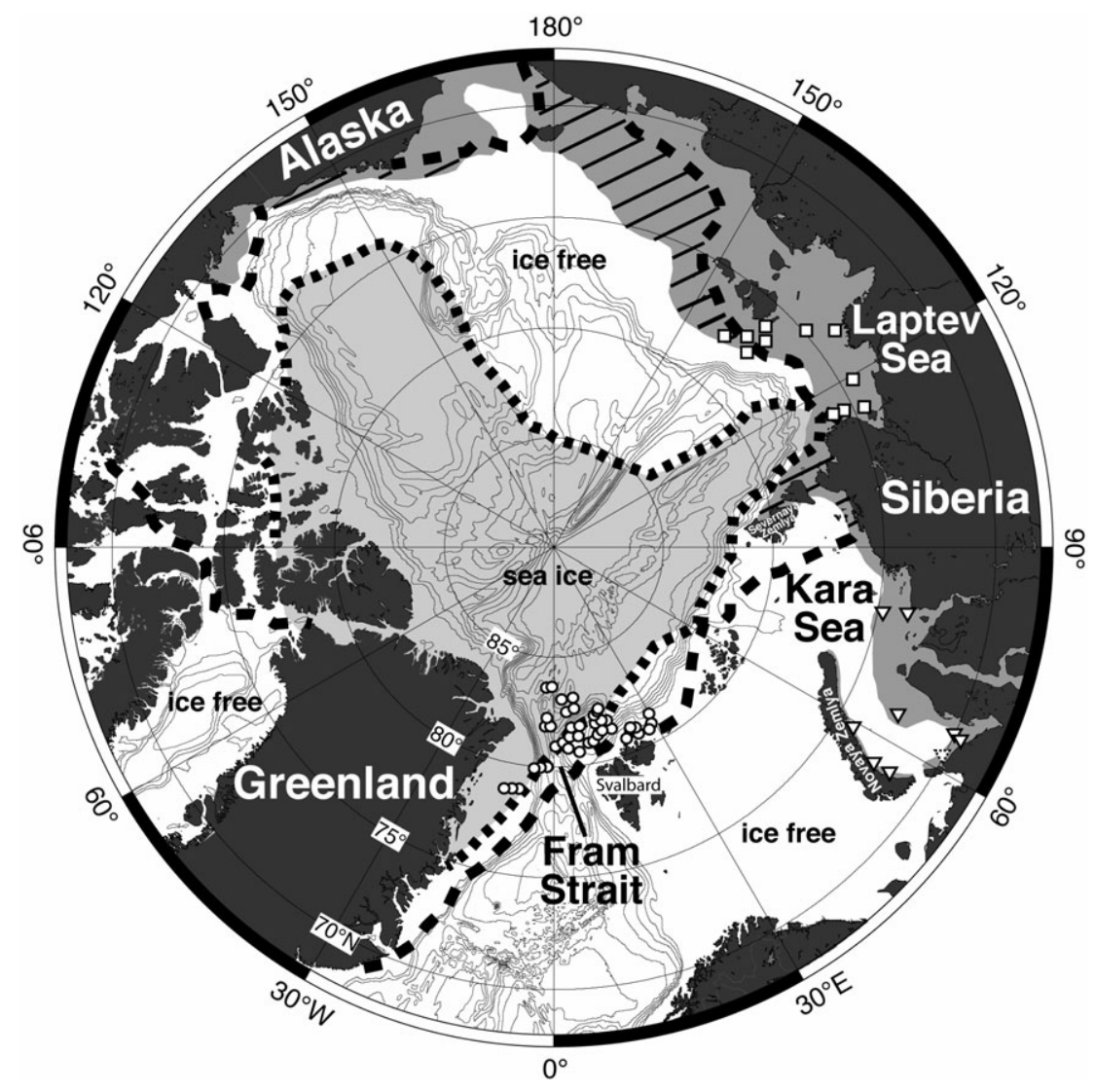

Fig. 1 Map of sampling locations in Fram Strait (circles), the Kara Sea (triangles) and the Laptev Sea (squares). The dashed bold line shows the minimum September sea-ice extent averaged for the 1973-76 period (Parkinson et al. 1987); this is similar to the median ice extent for September 1979-2000 (Overland et al. 2008). The September 2007 minimum Arctic sea-ice extent (Institute of Environmental Physics, University of Bremen; Overland et al. 2008) is displayed as a light-grey region surrounded by a stippled bold line. Dark-grey shelf areas indicate regions of less than $50 \mathrm{~m}$ water depth, generally available for turbulent sea-ice sediment entrainment. Hatched areas in the eastern Kara Sea, western and eastern Laptev Sea, East Siberian Sea, and the Chukchi and Beaufort seas indicate shelf areas of less than $50 \mathrm{~m}$ depth that are additionally available for late autumn and early winter sea-ice sediment entrainment subsequent to the current extreme summer ice retreat. The sample at the stippled triangle location in the south-western Kara Sea was obtained in 1997 (see text for more details). reaching 1000 to over $3000 \mathrm{mg} \mathrm{l}^{-1}$ (Osterkamp \& Gosink 1984; Larssen et al. 1987; Kempema et al. 1988; Reimnitz et al. 1993; Stierle \& Eicken 2002). Arctic SIS mostly consists of silt and clay; sand-sized particles are rare.

Arctic SIS shelf sources have been identified in various studies based on sedimentological, clay mineralogical and geochemical aspects (Elverhøi et al. 1989; Wollenburg 1993; Nürnberg et al. 1994; Eicken et al. 1997; Reimnitz et al. 1998; Darby 2003; Dethleff 2005). Numerical drift simulations (Pfirman et al. 1997; Harms et al. 2000) suggest that parts of the eastern Kara Sea and the entire Laptev Sea are the main contributors to Arctic SIS transport towards Fram Strait melt areas.

About $3000 \mathrm{~m}$ deep, Fram Strait is the ocean gateway between Svalbard and Greenland. It connects the central Arctic Ocean and the North Atlantic (Fig. 1). Over the last half of the 20th century, about $2900 \mathrm{~km}^{3}$ of sea ice left the central Arctic Ocean through Fram Strait and entered the North Atlantic annually (Vinje et al. 1998; Vinje 2001). Larssen et al. (1987) estimated the annual SIS flux in this ice at $150 \mathrm{Tg}(\mathrm{Mt})$. Arctic SIS is melt-released in Fram Strait and further south along the marginal ice zone year round (e.g., Hebbeln \& Wefer 1991). A higher sediment release can be expected in wintertime as a result of an increase of sea-ice flux resulting from the stronger atmospheric circulation during the polar night (Vinje 2001).

The Kara Sea is a semi-enclosed Siberian Arctic shelf sea bordered by Novaya Zemlya in the west and north, and by the Severnya Zemlya Archipelago to the east (Fig. 1). The sea is generally ice covered from November through June, and annually produces a total drift ice volume of about $900 \mathrm{~km}^{3}$, of which about $250 \mathrm{~km}^{3}$ is exported from the shelf and feeds the central Arctic Ocean pack ice (Kern et al. 2005; Martin \& Martin 2006). Our knowledge of the hydrodynamic mechanisms of turbulent SIS entrainment in the Kara Sea is primarily based on modelling efforts (Harms et al. 2000; Sherwood 2000; Smedsrud 2003). In a sedimentological study, Dethleff $\delta$ Kuhlmann (2009) investigated the entrainment of silt and clay into new ice formed in a shallow, coastal flaw lead (long extended open water between fast ice and drift ice) in the south-western Kara Sea. The study showed that newly incorporated SIS had the same composition as the shelf surface under the flaw lead.

The Laptev Sea is one of the broadest and shallowest shelf seas of the Arctic Ocean (Fig. 1). According to Zakharov (1966), the shelf sea annually produces 800$1000 \mathrm{~km}^{3}$ of new ice, of which about $250-300 \mathrm{~km}^{3}$ is 
formed in winter flaw leads (Dethleff, Loewe \& Kleine 1998). The ice exported from the Laptev Sea feeds the tail end of the Transpolar Drift (TPD). Rigor \& Colony (1997) found that the ice export from this shelf sea accounts for roughly $20 \%$ of the total annual ice flux through Fram Strait. Eicken et al. (2000) stated that as much as ca. $20 \mathrm{Tg}$ (Mt) of bottom sediments were incorporated into new ice formed close to the New Siberian Islands (Laptev Sea) during the autumn freeze-up over shallow open water (from $<17 \mathrm{~m}$ to $<30 \mathrm{~m}$ ) in one individual entrainment event in the 1994/95 season. Darby (2003) and Dethleff (2005) showed that shallow Laptev Sea winter polynyas and flaw leads are important sites for the entrainment of fine-grained bottom material into newly forming sea ice. The sediment-laden ice investigated in the above studies was advected offshore and transported through the TPD system towards Fram Strait.

Generally, the observed transit times of sea ice formed in the Kara and Laptev seas towards Fram Strait are 2-4 years (e.g., Colony \& Thorndike 1985; Eicken et al. 1997). However, these times may decrease significantly in the future with the acceleration of the TPD (Gascard et al. 2008).

The main purpose of this study is to compare SIS from northern Fram Strait and from north of Svalbard with the shelf-bottom deposits of shallow Kara and Laptev sea sites. We provide silt sedimentological and (statistical) clay mineralogical evidence ("fingerprints") for the ice transport of fine-grained particulate shelf material from the Siberian Arctic towards the northern North Atlantic. Based on the sedimentological and mineralogical data, we establish a west-to-east zoning of Fram Strait and northern Svalbard pack-ice provinces related to different Siberian shelf sediment source regions. We also determine the SIS content in northern Fram Strait ice-core transects and quantify the ice-sediment flux towards the North Atlantic in 1997 (the year of our principal investigation) and as multidecadal annual mean, both in combination with sea-ice export data from Vinje (2001). Moreover, we discuss the current ice entrainment and transport processes of Arctic SIS. Finally, we briefly speculate on Arctic SIS entrainment and transport related to the current dramatically changing ice situation on the shallow circum-Arctic shelves, and connected to summertime ice-free conditions that will potentially appear by the 2040s or 2050s (e.g., Holland et al. 2006).

\section{Materials and methods}

A total of 35 SIS samples were obtained in Fram Strait (Fig. 1) during the RV Polarstern cruise ARKXIII/2 (Stein \& Fahl 1997). Six SIS samples were taken during the ARKXV/3 cruise on the same vessel (Schauer 2000). The samples were taken from the ice surface, from pressure ridges, from meltwater ponds and from the uppermost core sections of multi-year ice floes. The ice was melted and the sediments were freeze-dried or filtered on preweighed mixed-ester membrane filters $(0.45-\mu \mathrm{m}$ pore diameter).

Three fjord bottom-surface samples were obtained along the eastern coast of Novaya Zemlya by box corer during Russian-Norwegian cruises in the 1990s (samples provided by the Norwegian Radiation Protection Authority). One bottom-sediment sample (Fig. 1) was obtained from the south-west Kara Sea during late winter 1997 (Dethleff, Loewe, Weiel et al. 1998) using an EkmanBirge grab (Hydrobios, Kiel, Germany). Five Kara Sea bottom samples (Fig. 1) were obtained by box corer during the 49th cruise of the RV Dmitry Mendeleev (samples provided by the P.P. Shirshov Institute of Oceanology, Moscow, Russia).

Seven bottom samples were collected in the eastern Laptev Sea using a small stainless steel grab during the East Siberian Arctic Region Expedition in 1992 (Dethleff et al. 1993), whereas the (clay mineral) data of four western Laptev Sea samples were re-analysed from Dethleff et al. (2000). All Kara and Laptev seas shelf samples were taken at water depths of less than $50 \mathrm{~m}$ (Fig. 1).

Simple semi-quantitative estimates (visual scan) of the mineralogical composition of the (coarse) bulk SIS and bottom samples were performed using a microscope, with 50-fold magnification (Leitz Aristoplan, Wetzlar, Germany). The particles were classified in the following groups: quartz and feldspar, rock fragments, mica, dark minerals, plant debris and other material.

All shelf surface and SIS samples were separated into S/S/C (sand, silt and clay) fractions. The sand fraction $(>63 \mu \mathrm{m})$ was obtained by wet sieving, and silt and clay fractions were gravitationally separated using the Atterberg method (Atterberg 1912). The grain size distribution of the silt fraction $(2-63 \mu \mathrm{m})$ was analysed using a SediGraph (Micromeritics, Norcross, GA, USA; see Coackley $\&$ Syvitski 1991 for further details). According to the silt grain size distribution, the samples were classified into silt types following Clark \& Hanson (1983) (Fig. 2). Sediment statistical parameters (median, mean, sorting, skewness and kurtosis) of the silt fraction were calculated following the method described by Folk \& Ward (1957). The percentages of silt subfractions (coarse: 63-20 $\mu \mathrm{m}$; medium: 20-6 $\mu \mathrm{m}$; fine: $6-2 \mu \mathrm{m}$ ) were determined from the SediGraph data.

The clay mineralogy of SIS and shelf bottom samples was determined using a PW $1830 \mathrm{X}$-ray diffractometer (copper-k-a radiation, 40 kv, 35 mA; Philips, Amstelplein, the Netherlands) within a spectrum from 2 to $462^{\circ} \mathrm{Q}$ in steps of $0.022^{\circ} \mathrm{Q} \mathrm{s}^{-1}$ using an automatic divergence slit, 

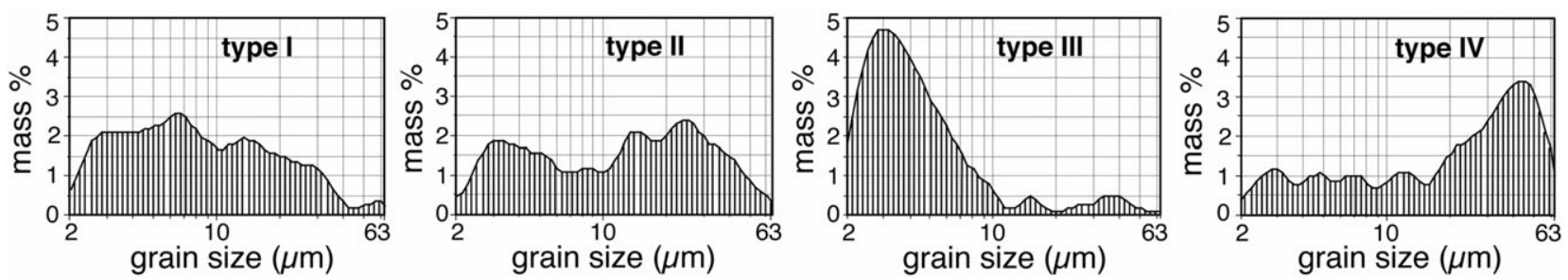

Fig. 2 Silt grain size distribution types in Fram Strait sea-ice sediments (SIS) according to the classification of Arctic deep-sea silt deposits transported by ice (introduced by Clark \& Hanson 1983). Type I is a non-sorted, ice-transported silt with a coarse fraction of about 20\%. Type II represents a bimodal, fine-grained, probably current-sorted ice-transported silt (before or after ice entrainment), with a coarse fraction of about $20 \%$. Type III reflects extremely fine-grained ice-rafted silt sediment with a mode in the silt-clay range, and little coarse material. Type IV is ice-transported silt with a pronounced medium to coarse silt mode associated with sand content of about $30 \%$.

graphite monochromator and automatic sample holder. The count time at each X-ray diffractometry step was $1 \mathrm{~s}$. Tucker (1996) provides a detailed description of this analytical method. Illite and smectite were determined from the 10- and 17- $\AA$ peaks, respectively, chlorite was determined from the third-order reflection, and kaolinite was calculated from the 7 - $\AA$ peak. The clay mineral percentages were calculated from peak areas following the procedure proposed by Biscaye (1965), and from peak intensities for kaolinite and chlorite after Petschick (Petschick et al. 1996). For comparison purposes, the results were normalized to $100 \%$ for the clay minerals illite, smectite, kaolinite and chlorite. Smectite content was determined after glycol-atmosphere treatment of the samples. Statistical Bray-Curtis similarity of clay mineral compositions between Fram Strait SIS and Kara and Laptev Sea bottom sediments was analysed using a multidimensional scaling (MDS) test (PRIMER v6; Primer-E Ltd., Ivybridge, Plymouth, UK).

For quantification of the annual SIS flux by the TPD through Fram Strait, we used the particle content of eight multi-year ice cores (Table 1) randomly obtained and nearly equally spaced on two transects north of the Fram Strait (Fig. 3b; stations 8, 12, 13 and 17, and stations 23, 24, 28 and 32) in 1997. The cores were subdivided widely into 10-cm sections; segments of cores with extreme SIS concentrations were further subdivided into $5-\mathrm{cm}$ sections. The ice was melted, the particle content of the core sections was filtered on pre-weighed mixed-ester membrane filters $(0.45-\mu \mathrm{m}$ pore diameter) and the particle load was determined in $\mathrm{mg} \mathrm{l}^{-1}$ melted sea ice.

\section{Results}

\section{SIS concentration}

The SIS sampled directly from the ice surface was most concentrated in meltwater ponds and in the extremely turbid layers of tilted floes in pressure ridges. Based on visual observations, the pack ice was most turbid in the eastern Fram Strait and north of Svalbard. The lengths of level ice cores obtained in the northern Fram Strait varied between 1.6 and $3.0 \mathrm{~m}$, and ice thicknesses increased from east to west. SIS concentrations in multi-year ice floes were generally highest in the upper core sections, and sometimes peaked at the core surface (Fig. 3c, Table 1). Discrete turbid layers were visible within individual ice cores. The range of sediment content in ice cores ranged from 0.0 to ca. $725.4 \mathrm{mg} \mathrm{l}^{-1}$. The upper turbid $80 \mathrm{~cm}$ of the ice cores contained sediment concentrations of less than ca. 3-300 $\mathrm{mg} \mathrm{l}^{-1}$, with extreme values exceeding $500 \mathrm{mg} \mathrm{l}^{-1}$. The lower ice-core sections generally contained particle loads of less than $5 \mathrm{mg} \mathrm{l}^{-1}$ throughout.

\section{Bulk sediment composition}

Quartz and feldspar were the most abundant coarse particle components (about 50-80\%) in all bulk SIS and shelf surface samples investigated. Rock fragments, mica, dark minerals, plant debris and other material were subordinate, or of minor abundance.

Sand-sized material was generally under-represented in most SIS samples (range 0-98.2\%, average 7.3\%; Tables 2, 3). Overall, $98 \%$ of the SIS samples clearly emphasized the fine fraction of less than $63 \mu \mathrm{m}$ in diameter, which was mainly dominated by silt (average $58.0 \%$; silt to clayey silt sediment type). The average clay concentration for all SIS samples was $33.7 \%$.

The shelf surface deposits of the Kara and Laptev seas contained slightly enhanced average sand content (10.8 and $12.2 \%$, respectively; Tables 2,3 ), as compared with the SIS, but silt was still the dominant grain size (average 58.3 and $45.4 \%$, respectively). The south-western Kara Sea (4, 8 and 9) showed particularly elevated sand content. The average clay percentage in Kara and Laptev shelf deposits was 30.8 and $42.4 \%$, respectively. For more 
Table 1 Sea-ice sediment (SIS) content in Fram Strait ice cores.

\begin{tabular}{|c|c|c|c|c|c|c|c|c|c|c|}
\hline \multirow{2}{*}{$\frac{\text { Core }}{\text { depth }(\mathrm{cm})}$} & \multicolumn{6}{|c|}{ SIS $\left(\mathrm{mg} \mathrm{I}^{-1}\right)$} & \multirow{2}{*}{$\frac{\text { Core }}{\text { depth }(\mathrm{cm})}$} & \multirow{2}{*}{$\frac{\mathrm{SIS}\left(\mathrm{mg} \mathrm{l}^{-1}\right)}{\# 12}$} & \multirow{2}{*}{$\frac{\text { Core }}{\text { depth }(\mathrm{cm})}$} & \multirow{2}{*}{$\frac{\text { SIS }\left(\mathrm{mg} \mathrm{l}^{-1}\right)}{\# 24}$} \\
\hline & \#8 & $\# 13$ & $\# 17$ & $\# 23$ & $\# 28$ & \#32 & & & & \\
\hline 0 to -10 & 0.247 & 68.269 & 9.241 & 0.000 & 501.331 & 91.068 & 0 to -5 & 725.359 & 0 to -10 & 41.323 \\
\hline-20 & 0.000 & 103.218 & 1.933 & 3.314 & 96.460 & 9.242 & -10 & 14.575 & -20 & 8.815 \\
\hline-30 & 0.000 & 146.522 & 3.718 & 4.465 & 58.455 & 16.142 & -20 & 7.303 & -30 & 5.054 \\
\hline-40 & 0.059 & 158.052 & 5.366 & 2.946 & 56.173 & 27.157 & -25 & 2.919 & -40 & 3.968 \\
\hline-50 & 0.000 & 75.270 & 5.944 & 3.336 & 52.807 & 31.551 & -30 & 14.968 & -50 & 5.072 \\
\hline-60 & 0.000 & 24.670 & 4.287 & 4.633 & 33.990 & 103.320 & -40 & 180.183 & -60 & 2.678 \\
\hline-70 & 0.000 & 5.054 & 3.779 & 5.376 & 39.898 & 340.425 & -45 & 18.196 & -70 & 2.791 \\
\hline-80 & 0.000 & 2.859 & 2.554 & 3.498 & 17.466 & 244.800 & -55 & 3.647 & -80 & 4.027 \\
\hline-90 & 0.000 & 2.048 & 2.926 & 4.786 & 4.239 & 22.905 & -60 & 52.804 & -90 & 3.883 \\
\hline-100 & 0.000 & 1.280 & 0.803 & 8.630 & 4.467 & 12.146 & -65 & 40.767 & -95 & 6.178 \\
\hline-110 & 0.000 & 4.414 & 0.417 & 5.343 & 3.419 & 6.504 & -75 & 6.785 & -105 & 20.726 \\
\hline-120 & 0.000 & 1.103 & 0.544 & 4.396 & 9.110 & 24.531 & -85 & 3.784 & -110 & 7.834 \\
\hline-130 & 0.147 & 1.924 & 0.279 & 0.679 & 4.174 & 11.823 & -95 & 1.494 & -120 & 15.619 \\
\hline-140 & 0.049 & 4.662 & 0.000 & 0.410 & 6.338 & 11.643 & -105 & 1.407 & -130 & 7.638 \\
\hline-150 & 0.000 & 5.702 & 0.194 & 0.414 & 20.893 & 29.264 & -115 & 2.826 & -140 & 0.000 \\
\hline-160 & 0.000 & 2.646 & 0.000 & 0.000 & 32.460 & 74.543 & -125 & 0.964 & -150 & 0.082 \\
\hline-170 & - & 5.265 & 0.000 & - & 31.121 & 595.571 & -135 & 1.016 & -160 & 2.920 \\
\hline-180 & - & - & 0.552 & - & 20.899 & 17.097 & -145 & 0.461 & -165 & 8.175 \\
\hline-190 & - & - & 0.272 & - & 7.394 & 2.059 & -155 & 0.262 & -170 & 5.748 \\
\hline-200 & - & - & 0.000 & - & 9.807 & 1.486 & -165 & 0.126 & -180 & 1.076 \\
\hline-210 & - & - & 1.096 & - & 10.745 & 1.738 & -175 & 0.000 & -190 & 0.646 \\
\hline-220 & - & - & - & - & 17.455 & - & -185 & 0.000 & -200 & 2.154 \\
\hline-230 & - & - & - & - & 5.802 & - & -195 & 0.110 & -210 & 0.855 \\
\hline-240 & - & - & - & - & 2.936 & - & -205 & 0.000 & -220 & 0.000 \\
\hline-250 & - & - & - & - & 0.423 & - & -215 & 0.160 & -230 & 0.102 \\
\hline-260 & - & - & - & - & 0.318 & - & -225 & 0.468 & -240 & 0.000 \\
\hline-270 & - & - & - & - & 0.109 & - & -235 & 0.193 & -250 & 0.000 \\
\hline-280 & - & - & - & - & 1.697 & - & & & & \\
\hline-290 & - & - & - & - & 2.035 & - & & & & \\
\hline-300 & - & - & - & - & 3.694 & - & & & & \\
\hline
\end{tabular}

granulometric details of the bulk sample composition see Tables 2 and 3.

\section{Silt fraction}

The fine-grained composition of the bulk SIS was underpinned by the high average fine silt content (59.0\%), and by the significantly lower medium and coarse silt fractions (average 28.1 and 12.9\%, respectively; Tables 2, 3). Kara and Laptev sea bottom silt was somewhat coarser grained, with a higher average coarse silt portion of 25.2 and $23.0 \%$, respectively, and with an enhanced average medium silt fraction of 32.4 and $51.3 \%$, respectively. More silt granulometric details, like sediment statistical parameters, are shown in Table 3, and are discussed below.

\section{Clay mineral assemblages}

Enhanced smectite values and lower illite concentrations in SIS were obvious in eastern Fram Strait and north of
Svalbard (Fig. 3b; Table 3). Significantly lower smectite contents associated with clearly enhanced illite concentration were present in the SIS from the western parts of Fram Strait.

Western Kara Sea bottom deposits from the east Novaya Zemlya coast contained no smectite and kaolinite, whereas illite and chlorite concentrations were significantly greater (Fig. 3d, Tables 1, 3). All other Kara Sea bottom samples had high portions of smectite, associated with lower contents of illite. Western Laptev Sea bottom deposits also showed high percentages of smectite and lower contents of illite, whereas eastern Lapetv Sea samples contained lower smectite and higher illite concentrations. Kaolinite and chlorite concentrations were much lower in the western Laptev Sea than in the eastern part (Tables 2, 3).

\section{Fram Strait SIS flux rate estimates}

For the assessment of a potential annual maximum, best estimate and minimum SIS flux through Fram Strait, we 


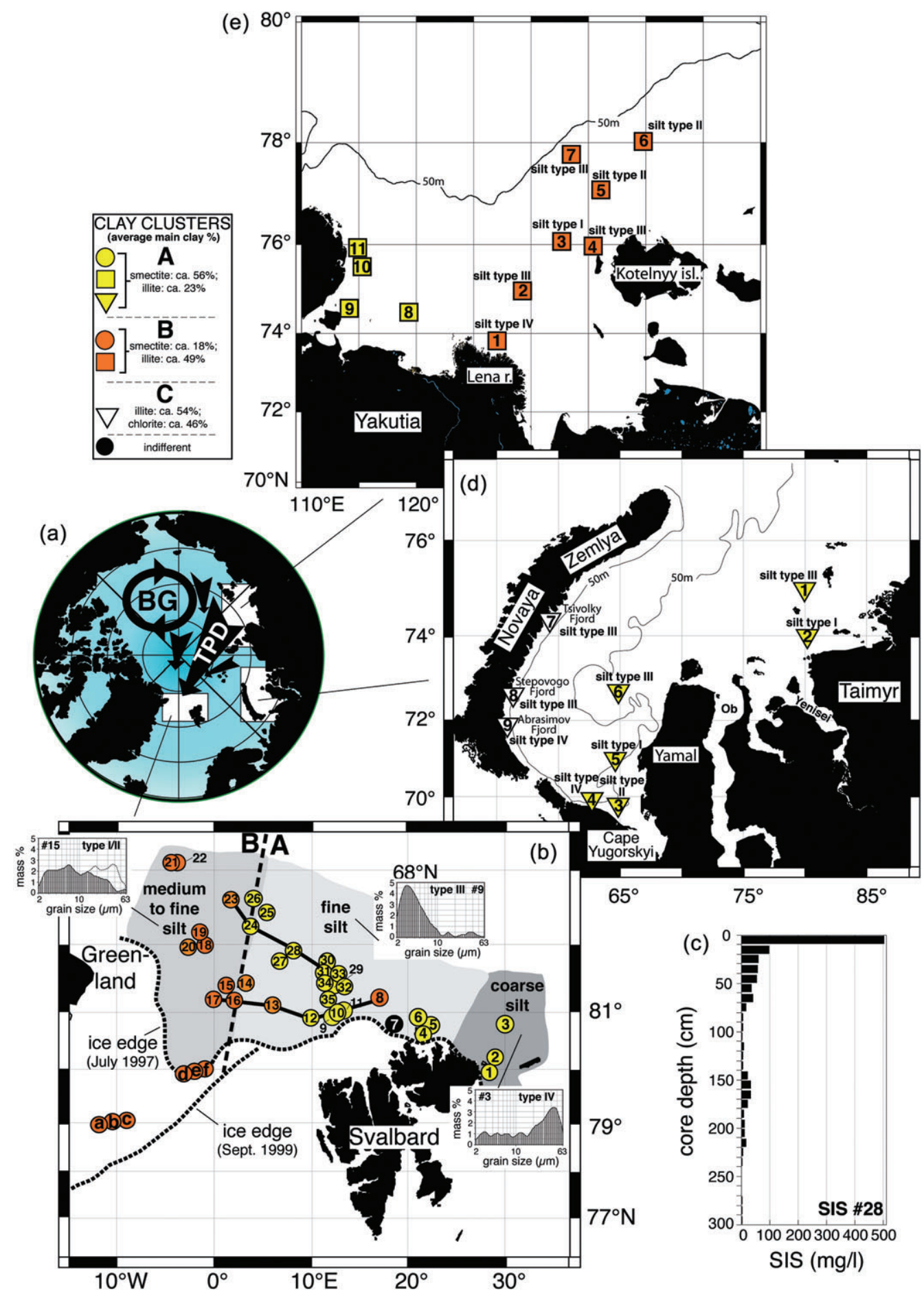

Fig. 3 (a) Arctic map displaying the Transpolar Drift (TPD) and the Beaufort Gyre (BG), and showing the areas of investigation. (b) Grey shaded areas display sea-ice sediment (SIS) silt type provinces emphasized by representative silt SEDIGRAPH histograms, according to the Clark \& Hanson (1983) classification. The dashed bold line separates Fram Strait SIS clay cluster provinces A and B, where numbers 1-35 relate to the 1997 RV Polarstern cruise, and letters a-f are linked to the 1999 Polarstern cruise. Solid bold west-east extended lines indicate 1997 ice-core cross sections in northern Fram Strait. The edge of closed pack ice on 25 July 1997 (stippled bold contour) is depicted from NOAA 12 satellite images received by the Polarstern as a temporary Arctic relays station. The September 1999 ice edge is based on information from the National Snow and Ice Center in Boulder. (c) Example of the vertical particle distribution in a central Fram Strait sea-ice core (see [b] for core location). (d) Kara Sea and (e) Laptev Sea sampling sites and shelf surface silt and clay mineral distributions. 
Table 2 Comprehensive sedimentological parameters of Fram Strait sea-ice sediments (SIS) and shelf deposits of the Kara and Laptev seas.

\begin{tabular}{|c|c|c|c|c|c|c|c|c|c|}
\hline & \multicolumn{3}{|l|}{ Fram SIS } & \multicolumn{3}{|l|}{ Kara shelf } & \multicolumn{3}{|l|}{ Laptev shelf } \\
\hline & Range & Average & SD & Range & Average & SD & Range & Average & SD \\
\hline Sand (wt\%) & $0-98.2$ & 7.32 & 16.54 & $0.2-33.7$ & 10.80 & 10.11 & $2.6-36.0^{b}$ & $12.23^{b}$ & $11.56^{\mathrm{b}}$ \\
\hline Silt (wt\%) & $0.90-75.4$ & 58.99 & 12.29 & $46.4-65.4$ & 58.30 & 6.20 & $15.0-64.5^{b}$ & $45.37^{b}$ & $16.65^{b}$ \\
\hline Coarse (wt\%) & $0.2-66.0^{\mathrm{a}}$ & $12.92^{\mathrm{a}}$ & $14.83^{\mathrm{a}}$ & $5.9-50.3$ & 25.16 & 17.38 & $13.9-31.6^{b}$ & $23.01^{b}$ & $5.72^{b}$ \\
\hline Medium (wt\%) & $12.0-41.6^{\mathrm{a}}$ & $28.07^{\mathrm{a}}$ & $8.94^{\mathrm{a}}$ & $24.8-42.5$ & 32.42 & 6.32 & $39.8-57.7^{b}$ & $51.29^{b}$ & $6.18^{b}$ \\
\hline Fine (wt\%) & $10.9-85.5^{a}$ & $59.01^{a}$ & $18.11^{\mathrm{a}}$ & $18.8-65.6$ & 42.42 & 17.03 & $18.0-36.7^{b}$ & $25.70^{b}$ & $5.91^{b}$ \\
\hline Median (phi) & $4.90-8.58^{\mathrm{a}}$ & $7.51^{\mathrm{a}}$ & $0.78^{\mathrm{a}}$ & $5.40-7.91$ & 6.91 & 0.92 & $5.89-7.58^{b}$ & $6.67^{b}$ & $0.57^{b}$ \\
\hline Mean (phi) & $5.31-8.38^{\mathrm{a}}$ & $7.48^{\mathrm{a}}$ & $0.68^{\mathrm{a}}$ & $5.68-7.81$ & 6.96 & 0.75 & $6.04-7.32^{b}$ & $6.71^{b}$ & $0.42^{b}$ \\
\hline Sorting & $0.57-1.76^{\mathrm{a}}$ & $1.21^{\mathrm{a}}$ & $0.28^{\mathrm{a}}$ & $0.97-1.89$ & 1.43 & 0.28 & $1.20-1.47^{b}$ & $1.32^{\mathrm{b}}$ & $0.10^{b}$ \\
\hline Skewness & -0.51 to $0.52^{\mathrm{a}}$ & $-0.06^{\mathrm{a}}$ & $0.21^{\mathrm{a}}$ & -0.33 to 0.37 & 0.06 & 0.22 & -0.38 to $0.18^{b}$ & $-0.07^{b}$ & $0.20^{\mathrm{b}}$ \\
\hline Kurtosis & $0.76-2.63^{\mathrm{a}}$ & $1.22^{\mathrm{a}}$ & $0.45^{\mathrm{a}}$ & $0.71-1.05$ & 0.85 & 0.11 & $0.69-1.09^{b}$ & $0.84^{b}$ & $0.13^{b}$ \\
\hline Clay (wt\%) & $0.90-60.0$ & 33.69 & 13.82 & $14.0-39.7$ & 30.80 & 7.04 & $29.3-53.9^{b}$ & $42.40^{b}$ & $7.75^{b}$ \\
\hline Smectite (\%) & $0.0-69.0$ & 38.06 & 20.92 & $0.0-64.0$ & 38.22 & 27.53 & $16.0-66.0$ & 34.36 & 21.77 \\
\hline Illite (\%) & $13.0-67.0$ & 35.00 & 16.30 & $17.0-60.0$ & 32.78 & 15.66 & $26.0-49.0$ & 40.36 & 8.37 \\
\hline Kaolinite (\%) & $2.0-19.0$ & 5.63 & 2.76 & $0.0-10.0$ & 4.67 & 3.65 & $4.0-25.0$ & 15.73 & 7.90 \\
\hline Chlorite (\%) & $11.0-33.0$ & 21.52 & 4.80 & $12.0-54.0$ & 24.33 & 15.74 & $1.0-16.0$ & 9.27 & 6.30 \\
\hline
\end{tabular}

${ }^{a}$ Without stations $a-f$.

${ }^{b}$ Without stations 8-10.

used the following method: the particle load of each individual ice core section (obtained in $\mathrm{mg} \mathrm{l}^{-1}$ meltwater; Table 1) was normalized to $\mathrm{gm}^{-3}$ of sea ice. We then multiplied this calculated SIS load with the annual seaice export through Fram Strait in 1997 (ca. $3300 \mathrm{~km}^{3}$; see Vinje 2001: fig. 3), and with the annual sea-ice export averaged over five decades (ca. $2900 \mathrm{~km}^{3}$; Vinje 2001). The maximum SIS flux was estimated using the average sediment content $\left(84.4 \mathrm{gm}^{-3}\right)$ in the upper $80 \mathrm{~cm}$ of the four most turbid ice cores (stations 12, 13, 28 and 32; Table 1), presuming that all ice exported through Fram Strait potentially contains such high sediment concentrations. For the best estimate we used the average ice core sediment concentration $\left(45.6 \mathrm{gm}^{-3}\right)$ from the upper $80 \mathrm{~cm}$ of all eight cores obtained, and the minimum estimate was calculated based on the average sediment concentration $\left(23.5 \mathrm{gm}^{-3}\right)$ of the entire ice cores.

The estimates of the annual Fram Strait SIS flux for the two sea-ice export scenarios $\left(2900 \mathrm{~km}^{3}\right.$ as the fivedecadal mean; $3300 \mathrm{~km}^{3}$ in 1997; Vinje 2001) are shown in Table 4. The maximum SIS flux amounted to 245 and $279 \mathrm{Tg}(\mathrm{Mt})$, respectively. The best-estimate sediment flux was 132 and $150 \mathrm{Tg}$ (Mt), whereas the minimum flux amounted to 68 and $78 \mathrm{Tg}(\mathrm{Mt})$, respectively. Average values from the maximum, best and minimum SIS flux estimates for both the 2900- and the $3300-\mathrm{km}^{3}$ ice export scenarios were 148 and $169 \mathrm{Tg}$ (Mt), respectively, with a final average of about $158 \mathrm{Tg}$ (Mt).

\section{Discussion}

\section{Fram Strait SIS provinces versus Siberian shelf sediment sources}

Arctic SIS are typically much finer grained (i.e., contain more silt and clay) than the circum-Arctic shelf source sediments, with a clear emphasis on the $2-63-\mu \mathrm{m}$ silt fraction (e.g., Reimnitz et al. 1998; Dethleff 2005; Dethleff \& Kuhlmann 2009). Clark \& Hanson (1983) identified four textural types (type I-IV) of icetransported fine-grained bottom sediment in the Arctic Ocean (compare Figs 2 and 3b), which rely widely on the silt distribution. Clark \& Hanson's type I represents a non-sorted sediment composition with a rather flat histogram. Type II is a bimodal distribution, with maxima in the fine silt/clay and in the medium silt. Type III represents a distribution with a strong mode in the fine silt and clay sizes, whereas type IV has a pronounced mode in the medium to coarse silt classes. Textural types I-III are related to pack ice rafting (Clark \& Hanson 1983). The general characteristics of the individual sediment types depend on shelf source sediments, hydrodynamics before and during ice entrainment, transport processes, release mechanisms and the depositional environment.

Detailed granulometric analyses of Fram Strait SIS show that most of the silt fractions match Clark \& Hanson's (1983) sediment types I, II and III (Fig. 3b, Table 3), which also occur widely on the shelf floors of the Kara and Laptev seas (Fig. 3d, e; Table 3). Based on 


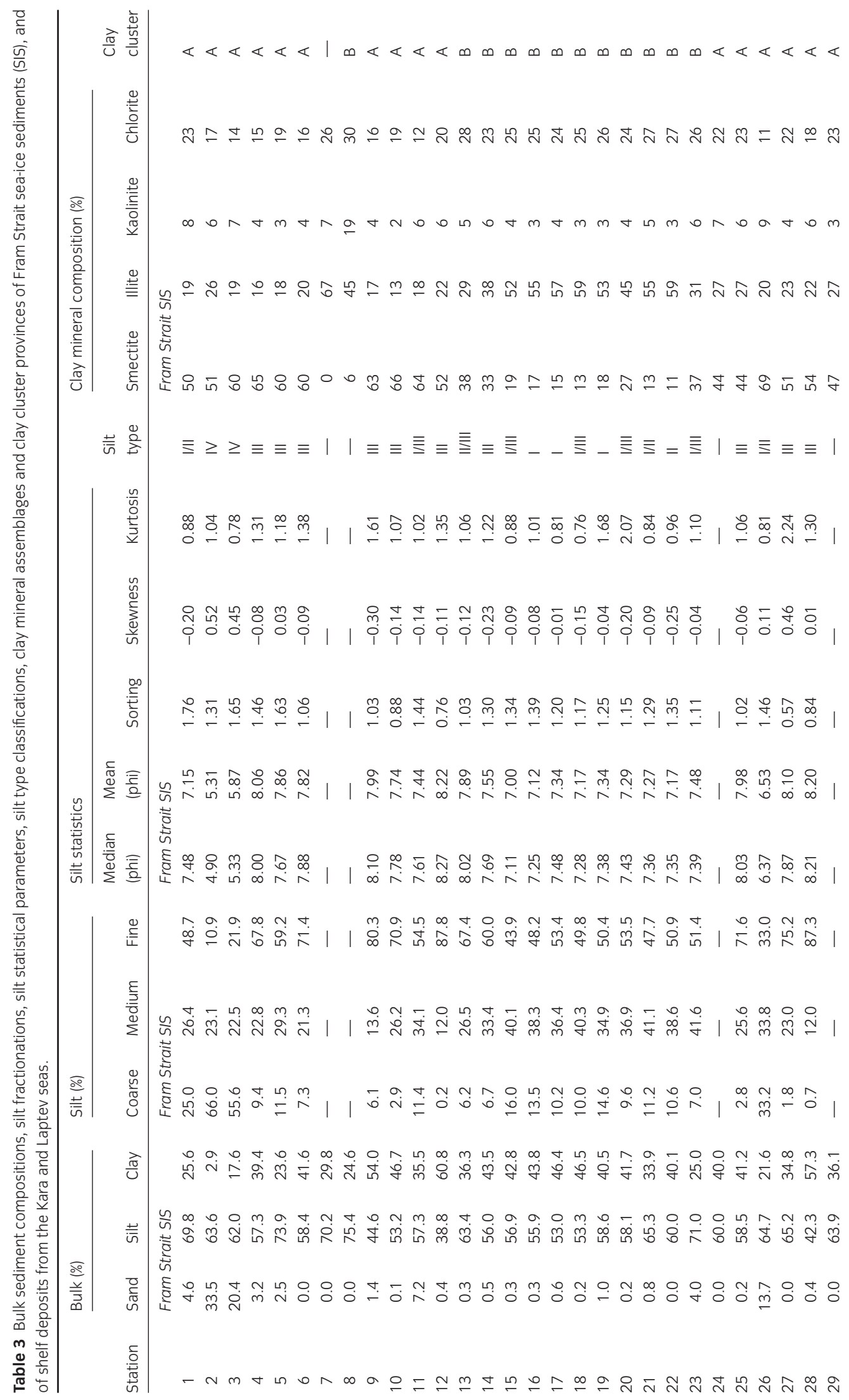




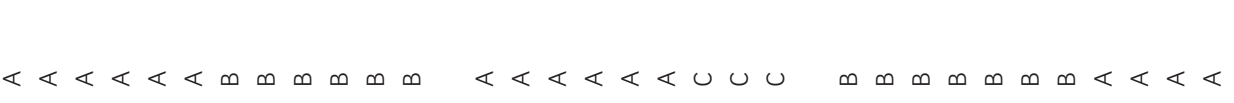

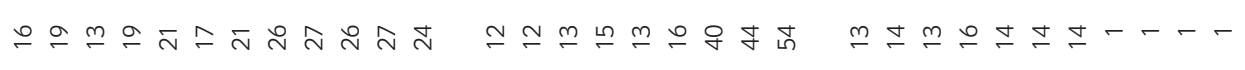
n ล กิกี่

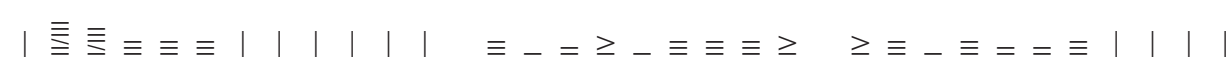

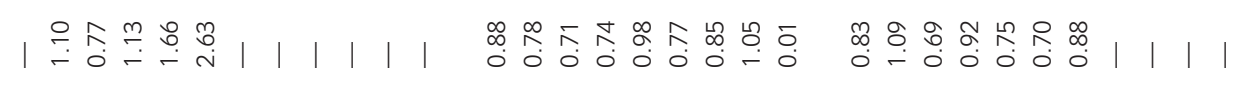

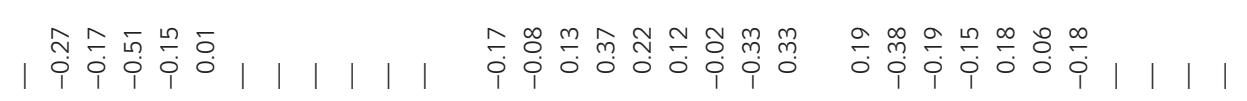

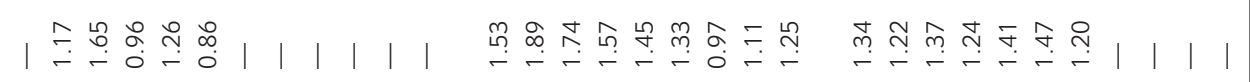

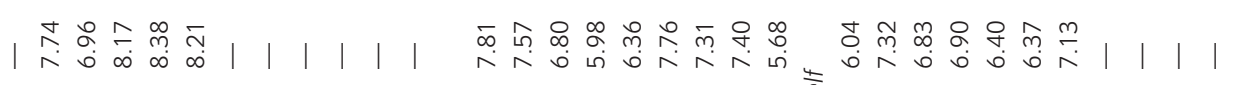

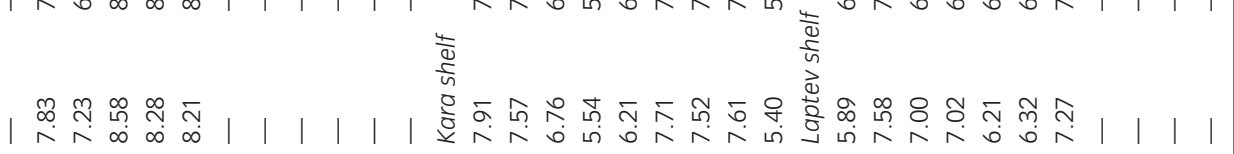
|

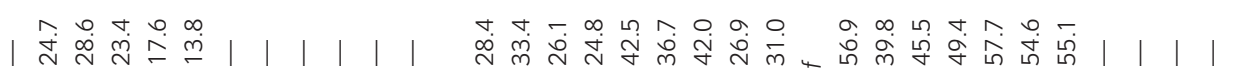

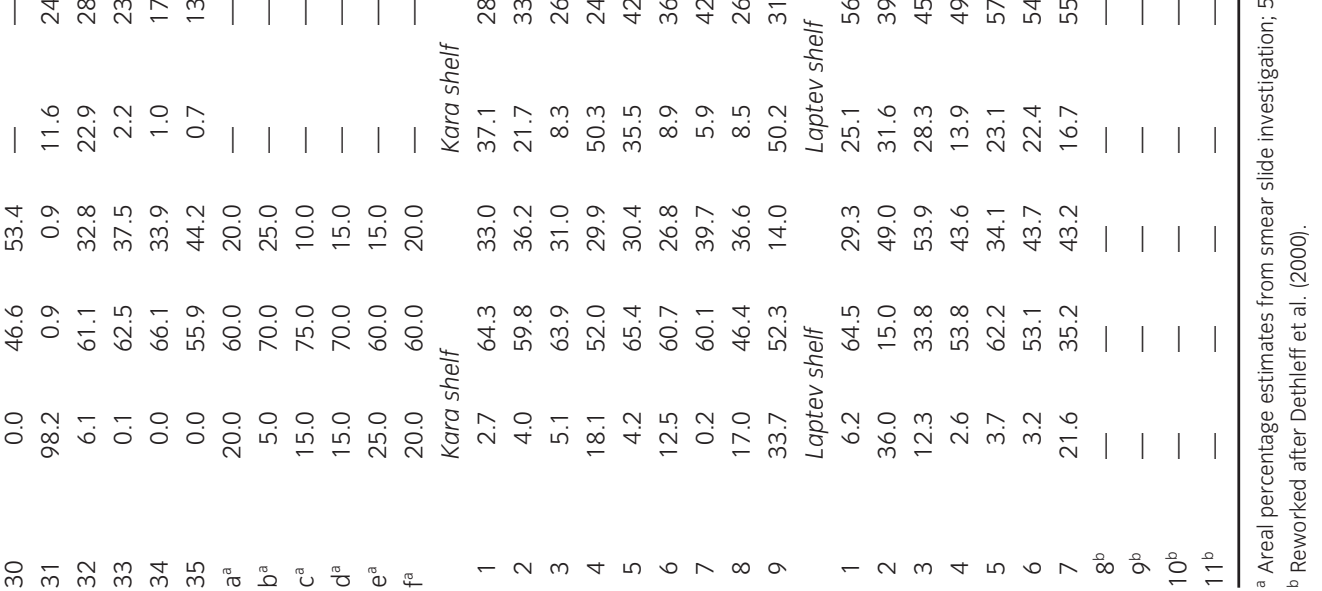


Table 4 Annual sea-ice sediment (SIS) flux through Fram Strait.

\begin{tabular}{|c|c|c|c|c|}
\hline Annual Fram Strait & \multicolumn{3}{|c|}{ SIS flux (Tg/106 t) } & \multirow{2}{*}{$\begin{array}{l}\text { SIS flux }\left(\mathrm{Tg} / 10^{6} t\right) \\
\text { Average } \\
\text { estimate }\end{array}$} \\
\hline ice export & $\begin{array}{l}\text { Maximum } \\
\text { estimate }\end{array}$ & $\begin{array}{l}\text { Best } \\
\text { estimate }\end{array}$ & $\begin{array}{l}\text { Minimum } \\
\text { estimate }\end{array}$ & \\
\hline $3300 \mathrm{~km}^{3}$ & 279 & 150 & 78 & 169 \\
\hline${ }^{b} 2900 \mathrm{~km}^{3}$ & 245 & 132 & 68 & 148 \\
\hline
\end{tabular}

a In 1997 (from Vinje 2001).

${ }^{b}$ Multidecadal mean (from Vinje 2001).

the Clark \& Hanson (1983) sediment types, we established SIS silt provinces in the pack ice of Fram Strait and north of Svalbard. Type-I and -II silts (medium to fine) were more persistent in the western Fram Strait ice province, whereas the eastern Fram Strait ice province is instead dominated by type-III silt (fine). Type-IV SIS silt (coarse) occurs north-east of Svalbard, and is attributed to ice rafting of coarse bottom material, if enhanced sand-sized material coincidently occurs in SIS (Clark \& Hanson 1983). This is partly the case northeast of Svalbard.

Figure $4 \mathrm{a}$ gives a first indication of the likely origin of Fram Strait SIS from Siberian shelf sea bottoms based on silt and clay distributions. As shown in Fig. 4a, the western Fram Strait SIS group with Laptev bottom sediments, and the eastern Fram Strait SIS cluster with Kara Sea shelf deposits. From the Clark \& Hanson (1983) silt type classification we conclude that about $50 \%$ of the Fram Strait SIS silt samples are less well sorted (types I or II; see Table 3). The silt statistical parameters "sorting" and "mean grain size" (Table 3) plotted in Fig. 4b support the results of our Clark \& Hanson classification, and show that about $77 \%$ of the SIS silt fractions are less well or even poorly sorted, and are at the same time extremely fine grained, with a mean grain diameter greater than 6.4 phi $(<12 \mu \mathrm{m}$; phi $=\log$ base 2 scale classifying particle sizes analogous to $\mathrm{mm} / \mu \mathrm{m})$. The same holds true for two-thirds of the Kara bottom-surface samples, and for $85 \%$ of the eastern Laptev Sea bottom sediments (western Laptev Sea bottom silts were not available). Plotting "skewness" against "mean grain size" (Fig. 4c) corroborates the consistency of the relationship between the extremely fine mean grain diameter (>6.4 phi) and the symmetrical to widely negative skewness of the silt distribution for about $90 \%$ of the SIS, and for about $50 \%$ for the Kara and Laptev Sea silt fractions, respectively.

Dethleff (2005) stated that about $80 \%$ of SIS silt samples investigated from the Laptev Sea, the East Siberian Sea and the Central Arctic are symmetrical to widely negatively skewed (fine), and that about $60 \%$ are moderately to well sorted. According to the Clark \& Hanson's (1983) sediment classification, the eastern and Central Arctic SIS correspond to type III. Conversely, in accordance with
Reimnitz et al. (1998: fig. 5), about 79\% of the extremely fine-grained SIS samples from the Beaufort Gyre, with a mean grain diameter greater than 6.4 phi $(<12 \mu \mathrm{m})$, are symmetrical to widely positively skewed, and about $77 \%$ of the samples are very poorly sorted. According to Clark \& Hanson's (1983) classification, the Beaufort Gyre SIS are of sediment types I and IV. The comparison shows that the Beaufort Gyre SIS samples are potentially somewhat coarser grained in the fine fraction than the Siberian SIS sample sets. We deduce from the mismatch of skewness between fine-grained SIS from the Beaufort Gyre and from the Siberian Arctic that silt sediment statistical parameters may help to identify the shelf origin of SIS, and conclude that most of the Fram Strait SIS examined in this study originated from Siberian shelf sources.

Looking more closely at the silt fraction, the Fram Strait SIS contained a total average of $89 \%$ medium and fine silt in the western part, and more than $92 \%$ in the eastern part, with an enhanced fine silt content of ca. 70\%. On average, Laptev SIS and bottom deposits both show the same high abundances of medium and fine silt (ca. 77\%; Dethleff 2005; this study). Dethleff \& Kuhlmann (2009) also found enhanced medium and fine silt content in the SIS of the south-western Kara Sea, with individual concentrations of more than $84 \%$, which is even higher than the average medium and fine silt content in Kara Sea shelf surface deposits (ca. 75\%) determined in the present study. We conclude that medium to fine silt is entrained into newly forming shelf sea ice in the same percentage as is available on the local bottom (Dethleff 2005), or in even higher portions through the preferential collection of angular to subangular discoidal silt particles (Dethleff \& Kuhlmann 2009) in the turbulent process of suspension freezing, particularly driven by Langmuir circulation (Dethleff et al. 2009). The high medium-to-fine silt content in shelf bottom deposits and shelf SIS is also reflected in the Fram Strait SIS.

Western Laptev Sea and the Kara Sea bottom sediments show high contents of smectite, whereas eastern Laptev, East Siberian and Chukchi seas bottom deposits, as well as North American and Canadian shelf source sediments, are dominated by illite throughout (Wahsner et al. 1999). Reimnitz et al. (1998) reported an average 

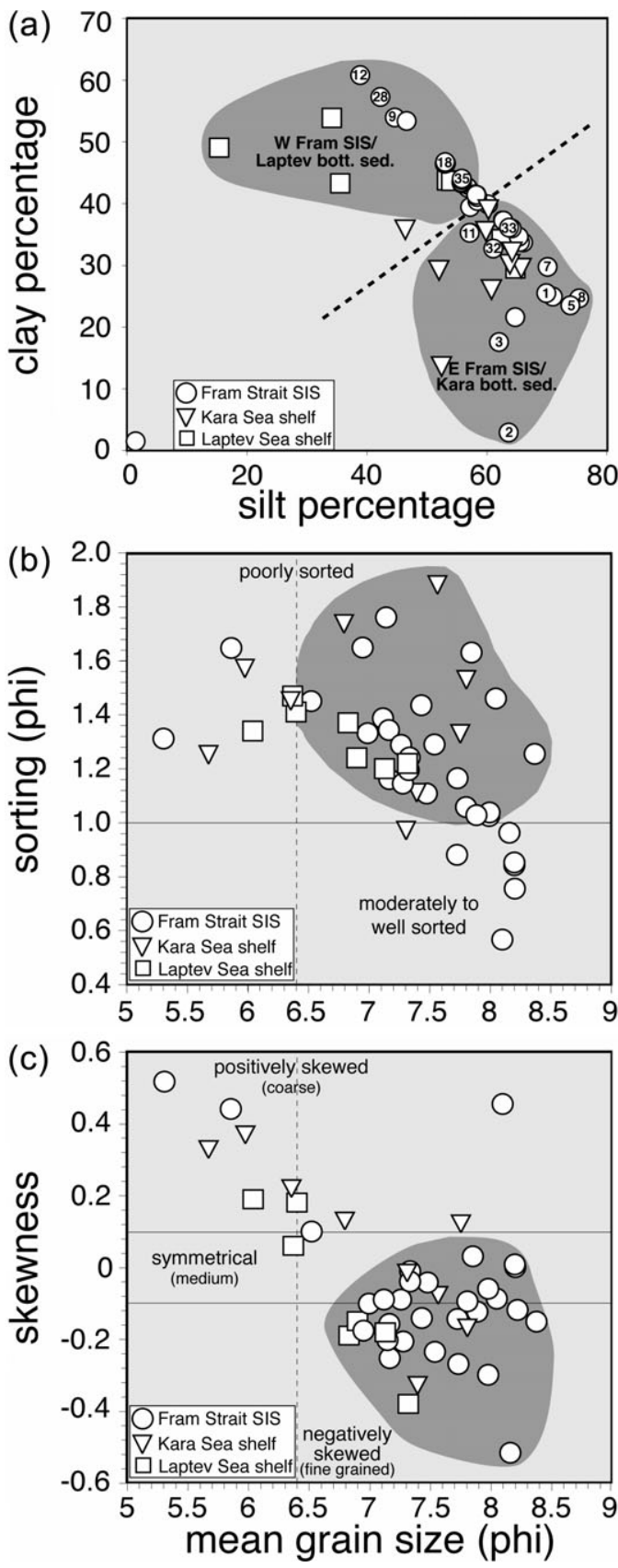

Fig. 4 (a) Groupings of 1997 western and eastern Fram Strait sea-ice sediments (SIS), with the probable Siberian shelf source bottom sediments (dark-grey areas). SIS station numbers are indicated. Diagrams of statistical SIS and Siberian shelf bottom silt parameters show (b) sorting versus mean grain size, and (c) skewness versus mean grain size.

SIS clay mineral composition of only $9 \%$ smectite and $11 \%$ kaolinite, but $57 \%$ illite and $23 \%$ chlorite in the Beaufort Gyre north of the Chukchi and Beaufort seas. Dethleff (2005) compared the average Laptev Sea SIS clay mineralogy (17\% smectite, 44\% illite, $25 \%$ kaolin- ite and $14 \%$ chlorite) with the SIS clay mineral compositions from the Reimnitz et al. (1998) study, and concluded that the mismatch between both mineral compositions may be used as a tool to roughly decipher the shelf origin of Arctic SIS between sources in the Eurasian Arctic and origins farther east and in the North American Arctic.

Average smectite and illite percentages in SIS of western and eastern Fram Strait show practically inverted values (smectite, 19 versus 56\%, 9.0 versus 7.7 SD, Table 3, stations 13-23, a-f; illite, 50 versus $21 \%, 9.3$ versus 4.0 SD, Table 3, stations 4-6, 9-12 and 24-35), whereas kaolinite and chlorite contents are similar (kaolinite, 5 versus 5\%, 2.0 versus $1.6 \mathrm{SD}$; chlorite, 25 versus $18 \%, 1.7$ versus $3.5 \mathrm{SD})$. Furthermore, the average western Fram Strait SIS smectite and illite contents are very similar to the average Laptev Sea SIS clay values (19 versus 17\%, and 50 versus $44 \%$, respectively; compare with Dethleff 2005), but the SIS of both regions have a clear mismatch in average kaolinite and chlorite percentages ( 5 versus $25 \%$ and 25 versus $14 \%$, respectively). Instead, the western Fram Strait SIS have a good match with the Beaufort Gyre illite and chlorite percentages (50 versus $57 \%$ and 25 versus $23 \%$, respectively), but show a mismatch in smectite (19 versus $9 \%$ ) and kaolinite ( 5 versus $11 \%)$ contents. From the above clay mineral data we assume that the western Fram Strait pack ice largely contained a mixture of floes originating from the Laptev Sea region (TPD system) and the North American Arctic (Beaufort Gyre), at least during the years of investigation. Conversely, the average eastern Fram Strait SIS clay mineral assemblage shows a significant mismatch with both the Laptev SIS (Dethleff 2005) and the Beaufort Gyre SIS (Reimnitz et al. 1998) in smectite, illite and kaolinite contents (smectite, 56 versus 17 versus 9\%; illite, 21 versus 44 versus $57 \%$; kaolinite, 5 versus 25 versus $11 \%$ ), which suggests an SIS origin from the westernmost Laptev Sea and the Kara Sea shelves, and also potentially from the region around Franz Josef Land, particularly for kaolinite-rich SIS (compare with Wahsner et al. 1999).

To strengthen the identification of potential shelf sources of Fram Strait SIS, the clay mineralogy data from the different regions investigated (Fram Strait, Kara and Laptev Sea shelves; Table 3) were statistically analysed using an MDS test assessing the resemblance of BrayCurtis similarities between all individual samples. Our test results show that all western Laptev Sea and most Kara Sea bottom clay compositions cluster with eastern Fram Strait and northern Svalbard SIS clays (cluster A; Figs. 3b, d, e, 5). This cluster depicts very high average smectite values $(>56 \%)$, and lower illite concentrations (ca. 23\%). Bottom clays of the Eastern Laptev Sea cluster with western Fram Strait SIS clays (cluster B) with low 


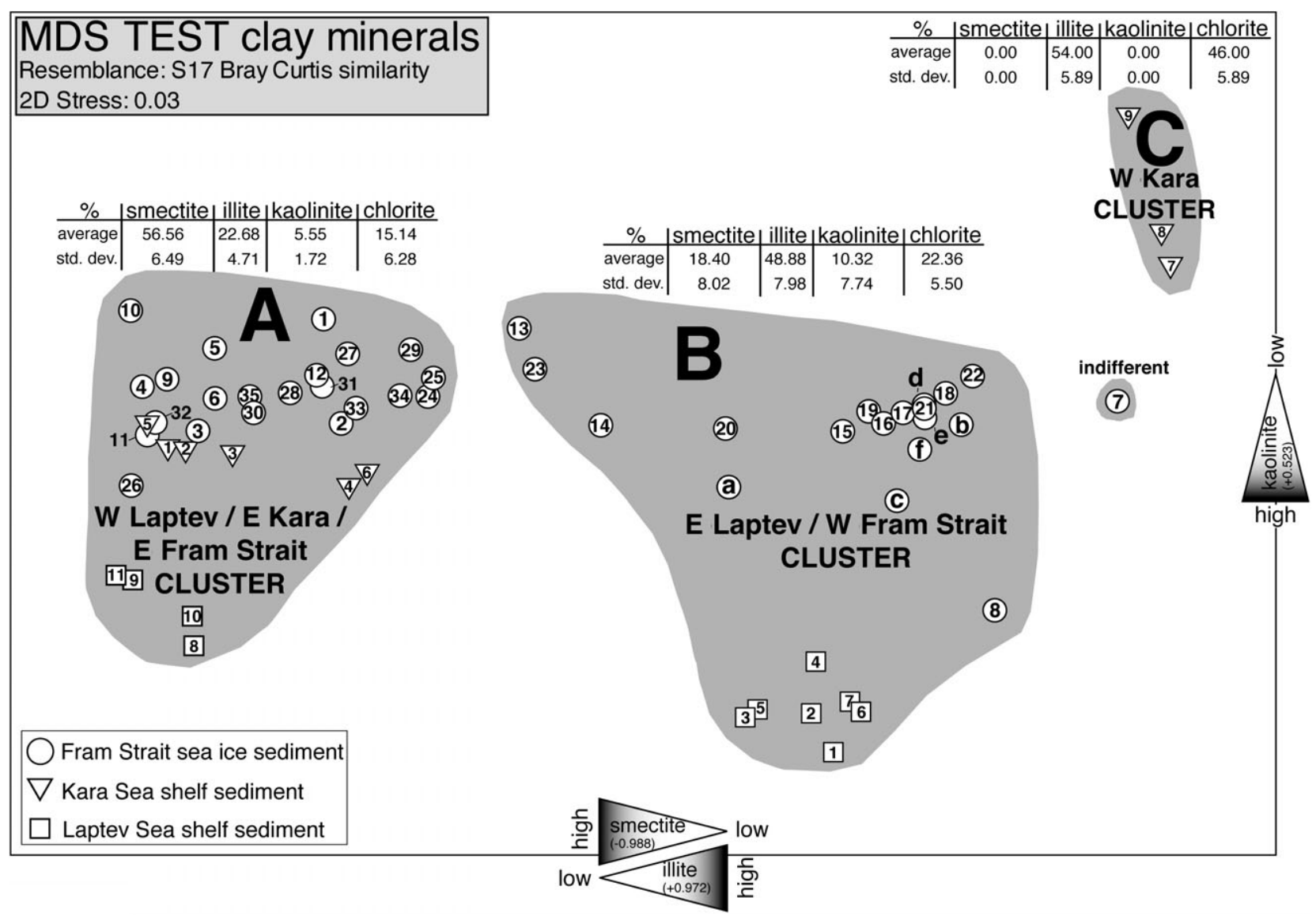

Fig. 5 Multidimensional scaling test results showing clay clusters A, B and C correlating with Fram Strait sea-ice sediments (SIS) and Siberian shelf surface deposits (clusters A and B). Cluster-related clay mineral averages and standard deviations are given in the tables within the figure. Clay mineral concentrations and correlation coefficients are indicated at the bottom and right-hand side of the figure.

average smectite (ca. 18\%) and high illite (ca. 49\%) contents. Cluster $\mathrm{C}$ is exclusively related to the western Kara Sea bay deposits, and has no mineralogical complement in Fram Strait SIS, at least during the seasons investigated. More individual average clay percentages are given in the cluster tables in Fig. 5.

\section{Current entrainment processes and transport of Arctic SIS}

Campbell \& Collin (1958) and Reimnitz et al. (1993, 1998) introduced the term "suspension freezing" to describe the formation of sediment-laden ice in the turbulent water column. Convective winter mixing in shallow open water like flaw leads and polynyas, penetrating down to the Arctic shelf, plays a crucial role in fine-grained sediment resuspension on Siberian shelves (Dmitrenko et al. 2005), and thus in the process of suspension freezing. Wind- and wave-induced Langmuir circulation (Drucker et al. 2003; Dethleff 2005; Kempema
\& Dethleff 2006) provide additional momentum to lift resuspended silt and clay particles up into the water column, and promote their incorporation into newly forming ice (Dethleff \& Kempema 2007; Dethleff \& Kuhlmann 2009). The widespread occurrence and persistence of the turbulent process of suspension freezing on the circum-Arctic shelves is documented in the prevailing fine-grained composition of SIS throughout the Arctic. Anchor ice also plays a role in Arctic SIS sediment entrainment (Reimnitz et al. 1992; Reimnitz et al. 1993), although it produces rather coarse sediment compositions, which we did not observe in our Fram Strait SIS samples.

Dethleff \& Kuhlmann (2009) discussed sorting processes and effects of bottom sediments prior to ice entrainment. The authors concluded that in a chain of various hydrodynamic or ice-related processes, the textural imprint of one event (e.g., turbulent resuspension) may be blended with the previous event (e.g., bottom current) and the following event (e.g., SIS entrainment), 
potentially resulting in SIS of a complex mixed nature. Also, secondary reworking of SIS through melt cycles may play a role in shaping the composition of ice sediments, although this would lead to scavenging of fine silt and clay particles, and to the enrichment of coarser particles. Dethleff \& Kuhlmann (2009) pointed out that the strength and persistence of bottom currents (e.g., tides) are hydrodynamic features that affect the size distribution of source sediments on the shallow shelf floor before SIS entrainment, but that hydrodynamic processes such as Langmuir circulation, orbital wave motion and thermohaline convection relate directly to turbulent sedimentice interaction in the water column, determining the size distribution of the sediments during entrainment into newly forming ice. The generally poor sorting of Fram Strait SIS and the bottom silt of Kara and Laptev seas reflects the short transport paths of both sediment groups before and during the process of entrainment, or even during melt-related reworking. While bottom silt originates from coastal erosion or local river discharge, SIS silt is floated up from the bottom by the process of suspension freezing into newly forming sea ice at depths down to about $40 \mathrm{~m}$. Dethleff \& Kuhlmann (2009) proposed that the latter process is related to a more constant energy level provided by continuous momentum through Langmuir circulation and thermohaline convection, as compared with the sea-floor environment during non-entrainment.

Kempema et al. (1988) stated that sediment-laden sea ice formed in near-shore locations of the Beaufort Sea could be advected into the Arctic Basin. Reimnitz et al. (1993) quantified the SIS export from a Beaufort Sea polynya to be $0.035 \mathrm{Tg}(\mathrm{Mt})$ per $\mathrm{km}$ of shelf parallel with the coast.

Eicken et al. (2005) estimated a 5-8 Tg (Mt) export of SIS from the entire Chukchi and Beaufort shelves for the 2001/02 season, representing a significant term in the sediment budget of the western Arctic Ocean.

Eicken et al. (2000) identified an individual SIS entrainment and export event of $18.5 \mathrm{Tg}(\mathrm{Mt})$ from the Laptev and East Siberian seas close to the New Siberian Islands in 1994/95, and Eicken et al. (1997) and Dethleff (2005) quantified the annual SIS export from the entire Laptev Sea to be greater than $20 \mathrm{Tg}$ (Mt). Harms et al. (2000) estimated an annual SIS sediment entrainment and export from eastern Kara Sea flaw leads off the $\mathrm{Ob}$ and Yenisei estuaries of about 2-3 Tg (Mt). The SIS entrainment and export from western Kara Sea flaw leads was estimated to be about $0.4 \mathrm{Tg}(\mathrm{Mt})$, whereas the export from the roughly 90-km-long Amderma/Vaygach lead in the south-west Kara Sea was expected to be at maximum about $0.077 \mathrm{Tg}(\mathrm{Mt})$ during the winter of 1996/97 (Nies et al. 1998).
The above studies point to just a few circum-Arctic SIS entrainment areas and events investigated and quantified in detail to date. However, more autumn shelf freezing water areas and potential winter polynyas (e.g., Dethleff, Loewe \& Kleine 1998: fig. 11; Winsor \& Björk 2000) are available for Arctic-wide SIS entrainment, which have not been investigated in detail yet. In this context, Eicken et al. (2005) made the point that the SIS export from the Siberian shelf seas is much more important than that of the North American shelves.

The transport pathways of Arctic SIS have been widely identified by simulation, backward trajectory calculations and drift buoy tracks, pointing generally to Eurasian shelves as potential source areas (e.g., Pfirman et al. 1997; Dethleff et al. 1997; Dethleff, Loewe, Weiel et al. 1998; Kuhlmann 1998; Harms et al. 2000). Nürnberg et al. (1994) and Dethleff et al. (2000) investigated the mineralogical composition of central Arctic SIS, which also point to the Siberian shelf seas as sources. Abelmann (1992) showed that marine/brackish diatom assemblages incorporated in sea ice in the central Arctic also indicate initial ice formation on the Siberian shelves. Darby (2003) found that sea ice formed in the Laptev Sea is an important factor for basin-wide sediment distribution. All studies show that most of the SIS incorporated on the circum-Arctic shelves are transported towards Fram Strait by the TPD.

Backward-trajectory simulations using the latitude and longitude of present SIS Fram Strait sea-ice sites were conducted with a simulation program provided by the Colorado Center for Astrodynamics Research, University of Colorado at Boulder. The back-trajectory model output widely supports our finding that western Fram Strait SIS corresponds to sources in the eastern Laptev Sea, and that eastern Fram Strait SIS tracks back to sources in the western Laptev and farther west. The model also shows that shelf source regions of Fram Strait SIS may differ from year to year. In this context Pfirman et al. (2004) report that the origins of multi-year Fram Strait sea ice have varied significantly over the past several decades. However, on average-and particularly for the 1996/97 season-the model results of Pfirman et al. (2004: fig. 1a, c) perfectly reflect the SIS sources and pathways identified in the present study based on sediment statistical analysis.

Our calculated mean annual SIS efflux of $158 \mathrm{Tg}(\mathrm{Mt})$ through Fram Strait confirms the magnitude of the annual SIS export estimated by Larssen et al. (1987; $150 \mathrm{Tg}[\mathrm{Mt}])$, and our maximum estimate (245-279 Tg [Mt]) may represent years with extreme SIS entrainment events and turbid Arctic sea-ice transport like that known from the 1994/95 season in the Laptev Sea (Eicken et al. 2000). However, it is also conceivable that the concen- 
trated upper SIS layers used in the maximum estimates may reflect a combination of both the "primary" suspension freezing process and the "secondary" reworking within the sea ice in response to albedo-induced melting of sediment-laden ice. This would tend to cause the estimate of the maximum SIS export to be somewhat higher than the actual value.

Nevertheless, the maximum estimate and the observations made by Eicken et al. (2000) strengthen the assumption made by Dethleff (2005) that a proposed figure of ca. $150 \mathrm{Tg}(\mathrm{Mt})$ SIS annually exported through Fram Strait is still a too low an estimate. The real figure may be in the magnitude of a quarter billion tonnes-like the maximum estimate in the 1997 season-considering the currently changing general ice situation in the Arctic Ocean and the changing ice origins and fluxes discussed below.

The interannual and interdecadal change of Fram Strait sea-ice origins (Pfirman et al. 2004) both quantitatively influence the overall trans-Arctic flux of SIS, as SIS export from individual circum-Arctic shelf seas differ significantly (Dethleff \& Kuhlmann 2009; also see above). However, through the decades the Laptev Sea shelf is undoubtedly one of the most constant producers of new ice in the Arctic, and one of the most constant exporters of SIS towards Fram Strait (Dethleff, Loewe \& Kleine 1998; Pfirman et al. 2004; Dethleff 2005). The Laptev Sea may control the long-term transpolar SIS transport most, but as a consequence this sea is also strongly subjected to coastal erosion (Are 1999; Rachold et al. 2000; Dethleff 2005).

\section{Future ice situation and SIS scenarios}

In a numerical simulation, Holland et al. (2006) showed a potential Arctic summer sea-ice decrease to 2 million $\mathrm{km}^{2}$ within a decade, and postulated near ice-free conditions by 2040 . However, various current studies on Arctic seaice decline show that the interannual reduction of sea-ice extent and thickness is progressing even faster than predicted (e.g., Stroeve et al. 2007; Haas et al. 2008).

Nghiem et al. (2007) report a current increase of ice loading into the TPD system accompanied by acceleration of the TPD, thereby exporting excessive ice through Fram Strait, which might also contribute to the reduction of the perennial ice cover. Acceleration of the TPD was also reported by Gascard et al. (2008), which was documented by the unusually fast $2000 \mathrm{~km}$ transit of the Tara ice camp from the northern Laptev Sea to Fram Strait, within only 15 months.

Eicken et al. (2005) proposed a likely increase of sediment-laden sea ice in the Chukchi and Beaufort seas subsequent to the reduction in summer ice extent, and the related increase of autumn fetch available for initial freezing during the late 1980s and early 1990s. Because of the accelerating summer Arctic ice retreat, autumn open water on the shallow Siberian and North American shelves is even more extended than a decade ago (e.g., Nghiem et al. 2007, Stroeve et al. 2007; see Fig. 1). The significant summer ice retreat provides open-water conditions for sediment entrainment into newly forming frazil and grease ice, in large, shallow shelf areas that have hitherto not been available for new ice formation in late autumn and winter (Fig. 1).

In general, we expect no major qualitative changes in the nature of SIS entrainment processes on the shallow circum-Arctic shelves as a result of the reduction of summer ice extent. However, the current increase in autumn shelf fetch related to the late summer ice retreat will cause more extreme wave height and swell on shallow Arctic shelves (Eicken et al. 2005). This provides momentum for additional sediment mobilization from the shelf bottom (Sherwood 2000), and can thus increase the quantity of sediment entrained into newly forming ice. Finally, more sediment-laden ice can currently potentially be formed on the circum-Arctic shelves during autumn and winter. This, combined with the current acceleration of the TPD, will increase SIS transport through the Fram Strait in the near future.

In the event of a completely ice-free Arctic Ocean in summer by the 2040-2050s (Holland et al. 2006), or even by the next decade (Maslowski 2008), the Arctic Ocean will not only entirely lose its role in keeping the north polar region cool and controlling the global climate, but additionally in the more distant future the SIS transport by the TPD would be disrupted at least seasonally. If multi-year ice is then completely displaced by first-year ice in the central Arctic Ocean-a current, dramatic ongoing trend (Haas et al. 2008)-SIS incorporated in the shallow shelves during the autumn freeze-up and in larger winter flaw leads (Eicken et al. 2005) will be released in the central Arctic Ocean during the next summer melt, and will not reach Fram Strait. This would lead to a drastically changing sedimentation regime in the central Arctic Ocean, and to reduced sediment deposition in the North Atlantic Ocean.

\section{Conclusions}

From our investigation of Fram Strait SIS and Arctic shelf bottom sediments we conclude the following:

- Sea ice was generally more turbid in the eastern Fram Strait than in the western part, and Fram Strait ice thicknesses increased from east to west. SIS was most enhanced in the upper $80-\mathrm{cm}$ part of ice cores, with concentrations of 3 to ca. $300 \mathrm{mg} \mathrm{l}^{-1}$, and showed an 
absolute maximum of ca. $725 \mathrm{mg} \mathrm{l}^{-1}$. Fram Strait SIS had a lower average sand content than shelf deposits of the Kara and Laptev seas (<6\% versus $11 / 12 \%)$. Silt was the dominating fraction in both SIS and Kara and Laptev bottom deposits (average ca. 58 versus $58 / 45 \%$ ), whereas clay occurred with ca. 36\% (SIS) and $31 / 42 \%$ (Kara/Laptev bottom sediments). The overall qualitative composition of SIS and shelf sediments was dominated by similar quartz and feldspar contents. The generally fine-grained texture of Fram Strait SIS was underpinned by enhanced average fine silt content (ca. 59\%) and low coarse silt (ca. 13\%), whereas the somewhat coarser Kara and Laptev bottom sediments showed notably enhanced coarse $(25 / 23 \%)$ and medium silt fractions (ca. 32/51\%).

- The silt fractions of SIS and Kara and Laptev bottom deposits match Clark \& Hanson's (1983) medium to fine-grained types I, II and III. Based on silt type distribution and clay mineral clusters, we established Fram Strait SIS provinces related to Siberian shelf sediment sources. Western Fram Strait SIS containing lowsmectite/high-illite composition and medium-to-fine silt correlate with eastern Laptev Sea shelf deposits, and were also similar to North American Arctic shelf source sediments. Eastern Fram Strait SIS with high-smectite/ low-illite concentrations and fine silt content relate to western Laptev Sea and Kara Sea bottom sediments. We propose that at least during the periods of investigation (1997-99), the western Fram Strait ice pack consisted of floes originating from the eastern Laptev Sea and shelf regions east of that (East Siberian Sea towards North American Arctic), and that the eastern Fram Strait sea ice mainly originated from the western Laptev Sea and the Kara Sea.

- Combining sediment concentrations in Fram Strait ice cores with annual (1997) and multidecadal ice export rates (Vinje 2001), we estimated the potential maximum, best estimate, and minimum SIS flux towards the North Atlantic. Maximum SIS flux estimates for annual $\left(3300 \mathrm{~km}^{3}\right)$ and multidecadal $\left(2900 \mathrm{~km}^{3}\right)$ ice export rates showed values of 279 and $245 \mathrm{Tg}(\mathrm{Mt})$, respectively. The best estimate revealed an SIS flux through Fram Strait of 150 and $132 \mathrm{Tg}$ (Mt), and the minimum flux amounted to 87 and $68 \mathrm{Tg}(\mathrm{Mt})$. The overall average estimate of ca. $158 \mathrm{Tg}$ (Mt) of SIS annually fluxing through Fram Strait is in good agreement with figures proposed in other studies (Larssen et al. 1987; Dethleff 2005).

- Present entrainment of SIS on circum-Arctic shelves is predominantly driven by the process of suspension freezing (turbulent incorporation of fine-grained sediment into newly forming ice in wind-driven open water during the freezing period). We do not expect changes in the process of suspension freezing itself to result from increasing summer Arctic ice retreat. However, we anticipate that in the near future more SIS will be entrained subsequent to enhanced fetch on the circum-Arctic shelves during the start of freezing period, and we presume that there will be increased SIS export through Fram Strait as a result of the acceleration of the TPD. In future, when the perennial pack ice may be completely substituted by first-year ice as a result of an ice-free Arctic Ocean in summer, all SIS entrained on the circum-Arctic shelves will be melt-released in the central Arctic Ocean, and will not reach Fram Strait or the North Atlantic Ocean.

\section{Acknowledgements}

This study was financially supported by the Federal Minstry for the Environment, Nature Conservation and Nuclear Safety, Germany (project StSch 4101; 1996-99). The content of this paper does not necessarily reflect the opinion of the ministry. We are indebted to Peter Loewe, Dominik Weiel and our Russian colleagues from the Murmansk Marine Biological Institute for their great help during the Kara Sea expedition. We are also grateful to Dirk Nürnberg and Erk Reimnitz for their help during the Laptev Sea fieldwork. Many helping hands onboard the RV Polarstern are thanked for obtaining the sea-ice sediments during the ARKXIII/2 and ARKXV/3 cruises. We are further indebted to Michael Levitan from the P.P. Shirshov Institute of Oceanology in Moscow for providing sediment samples from the 49th cruise of the RV Dmitry Mendeleev. Moreover, we are grateful to our Norwegian colleagues Per Strand and Bjørn Lind from the Norwegian Radiation Protection Authority, as well as to Lars Føyn from the Institute of Marine Research, University of Bergen, for kindly providing surface sediment samples of the eastern Novaya Zemlya fjords. We are thankful to Amelie Winkler for conducting clay mineral analysis of the Polarstern ARKXV/3 ice sediment samples. Dieter Piepenburg is thanked for help with the statistical analysis, and we are grateful to Ed Kempema for reading and improving our manuscript. Charles Fowler, University of Colorado at Boulder, provided his simulation program for Fram Strait SIS backward-trajectory calculations. Finally, we thank one anonymous reviewer and Joseph Ortiz for their helpful reviews of the manuscript.

\section{References}

Abelmann A. 1992. Diatom assemblages in Arctic sea ice-indicator for ice drift pathways. Deep-Sea Research Part I $39,525-538$. 
Are F. 1999. The role of coastal retreat for sedimentation in the Laptev Sea. In H. Kassens et al. (eds.): Land-ocean systems in the Siberian Arctic: dynamics and history. Pp. 287-295. Berlin: Springer.

Atterberg A. 1912. Die mechanische Bodenanalyse und die Klassifikation der Böden Mittelschwedens. Internationale Mitteilungen für Bodenkunde. Bd. II. (Mechanical soil analysis and classification of the soils of central Sweden. International Bulletin of Soil Science. Vol. 2.) Berlin: Verlag für Fachliteratur.

Biscaye P.E. 1965. Mineralogy and sedimentation of recent deep-sea clay in the Atlantic Ocean and the adjacent seas and oceans. Geological Society of America Bulletin 76, 803-832.

Campbell N.J. \& Collin A.E. 1958. The discoloration of Foxe Basin ice. Journal of Fishery Research Board Canada 15, 1175-1188.

Clark D.L. \& Hanson A. 1983. Central Arctic Ocean sediment texture: a key to ice transport mechanisms. In B.F. Molina (ed.): Glacial-marine sedimentation. Pp. 301-330. New York: Plenum Press.

Coackley J.P. \& Syvitski J.P. 1991. SediGraph technique. In J.P. Syvitski (ed.): Principles, methods and application of particle size analysis. Pp. 129-142. Cambridge: Cambridge University Press.

Colony R. \& Thorndike A.S. 1985. Sea ice motion as a drunkard's walk. Journal of Geophysical Research-Oceans 90, 965-974.

Darby D.A. 2003. Sources of sediment in sea ice from the western Arctic Ocean, new insights into processes of entrainment and drift patterns. Journal of Geophysical Research-Oceans 108, 3257, doi: 10.1029/2002 JC001350.

Dethleff D. 2005. Entrainment and export of Laptev Sea ice sediments, Siberian Arctic. Journal of Geophysical Research-Oceans 110, C07009, doi: 10.1029/ 2004JC002740.

Dethleff D. \& Kempema E.W. 2007. Langmuir circulation driving sediment entrainment into newly formed ice-tank experiment results with application to nature (Lake Hattie, USA; Kara Sea, Siberia). Journal of Geophysical Research-Oceans 112, CO2004, doi: 10.1029/ 2005JC003259.

Dethleff D., Kempema E., Koch R. \& Chubarenko I. 2009. On the helical flow of Langmuir circulationapproaching the process of suspension freezing. Cold Regions Science and Technology, doi: 10.1016/ j.coldregions.2008.10.002.

Dethleff D. \& Kuhlmann G. 2009. Entrainment of fine-grained surface deposits into new ice in the southwestern Kara Sea, Siberian Arctic. Continental Shelf Research, doi: 10.1016/j.csr.2008.11.009.

Dethleff D., Kuhlmann G., Nürnberg D., Harms I.H., Karcher M., Nies H., Rigor I. \& Shipboard Scientific Party RV Polarstern ARKXIII/2. 1997. Drift of sediment-laden Arctic sea ice- preliminary results from 1997 ARKXIII/2 RV "Polarstern" cruise and numerical model studies. EOS, Transactions of the
American Geophysical Union 78. San Francisco: American Geophysical Union.

Dethleff D., Loewe P. \& Kleine E. 1998. The Laptev Sea flaw lead-detailed investigation on new ice formation and export during 1991/92 winter season. Cold Regions Science and Technology 27, 225-243.

Dethleff D., Loewe P., Weiel D., Nies H., Kuhlmann G., Bahe C. \& Tarasov G. 1998. Winter expedition to the southwestern Kara Sea-investigations on formation and transport of turbid sea-ice. Reports on Polar Research 271. Bremerhaven: Alfred Wegener Institute for Polar and Marine Research.

Dethleff D., Nürnberg D., Reimnitz E., Saarso M. \& Savchenko Y.P. 1993. East Siberian Arctic Region Expedition '92: the Laptev Sea-its significance for Arctic sea ice formation and transpolar sediment flux. Reports on Polar Research 120. Bremerhaven: Alfred Wegener Institute for Polar and Marine Research.

Dethleff D., Rachold V., Tintelnot M. \& Antonov M. 2000. Sea-ice transport of riverine particles from the Laptev Sea to Fram Strait based on clay mineral studies. International Journal of Earth Sciences 89, 496-502.

Dmitrenko I.A., Tyshko K.N., Kirillov S.A., Eicken H., Hölemann J.A. \& Kassens H. 2005. Impact of flaw polynyas on the hydrography of the Laptev Sea. Global and Planetary Change 48, 9-27.

Drucker R., Martin S. \& Moritz R. 2003. Observations of ice thickness and frazil ice in the St. Lawrence Island polynya from satellite imagery, upward looking sonar, and salinity/ temperatury moorings. Journal of Geophysical

Research-Oceans 108, 3149, doi: 10.1029/2001JC001213.

Eicken H., Gradinger R., Graves A., Mahoney A. \& Rigor I. 2005. Sediment transport by sea ice in the Chukchi and Beaufort seas: increasing importance due to changing ice conditions? Deep-Sea Research Part II 52, 3281-3302.

Eicken H., Kolatschek J., Freitag J., Lindemann F., Kassens H. \& Dmitrenko I. 2000. A key source area and constraints on entrainment for basin-scale sediment transport by Arctic sea ice. Geophysical Research Letters 27, 1919-1922.

Eicken H., Reimnitz E., Alexandrov V., Martin T., Kassens H. \& Viehoff T. 1997. Sea-ice processes in the Laptev Sea and their importance for sediment export. Continental Shelf Research 17, 205-233.

Elverhøi A., Pfirman S.L., Solheim A. \& Larssen B.B. 1989. Glaciomarine sedimentation in epicontinental seas exemplified by the northern Barents Sea. Marine Geology $85,225-250$.

Folk R.L. \& Ward W.C. 1957. Brazos river bar: a study in the significance of grain size parameters. Journal of Sedimentary Petrology 27, 3-26.

Gascard J.-C., Festy J., le Goff H., Weber M., Bruemmer B., Offermann M., Doble M., Wadhams P., Forsberg R., Hanson S., Skourup H., Gerland S., Nicolaus M., Metaxian J.-P., Grangeon J., Haapala J., Rinne E., Haas C., Heygster G., Jakobson E., Palo T., Wilkinson J., Kaleschke L., Claffey K., Elder B. \& Bottenheim J. 2008. Exploring Arctic Transpolar Drift during dramatic sea ice retreat. 
EOS, Transactions of the American Geophysical Union 89, 21-28.

Haas C., Pfaffling A., Hendricks S., Rabenstein L., Etienne J.-L. \& Rigor I. 2008. Reduced thickness in Arctic Transpolar Drift favors rapid ice retreat. Geophysical Research Letters 35, L17501, doi: 10.1029/2008GL034457.

Harms I.H., Karcher M.J. \& Dethleff D. 2000. Modeling Siberian river runoff-implications for contaminant transport in the Arctic Ocean. Journal of Marine Systems 27, 95-115.

Hebbeln D. \& Wefer G. 1991. Effects of ice coverage and ice-rafted material on sedimentation in the Fram Strait. Nature 350, 409-411.

Holland M.M., Bitz C.M. \& Tremblay B. 2006. Future abrupt reductions in the summer Arctic sea ice. Geophysical Research Letters 33, L23503, doi: 10.1029/2006GL028024.

Kempema E.W. \& Dethleff D. 2006. The role of Langmuir circulation in suspension freezing. Annals of Glaciology 44, 58-62.

Kempema E.W., Reimnitz E. \& Barnes P.W. 1988. Sea ice sediment entrainment and rafting in the Arctic. Journal of Sedimentary Petrology 59, 308-317.

Kern S., Harms I., Bakan S. \& Chen Y. 2005. A comprehensive view of Kara Sea polynya dynamics, sea-ice compactness and export from model and remote sensing data. Geophysical Research Letters 32, L15501, doi: 10.1029/2005GL023532.

Kuhlmann G. 1998. Eintrag und Transport von Sedimenten im arktischen Meereis am Beispiel der südwestlichen Karasee und nördlichen Framstraße. (Entrainment and transport of sediment in Arctic sea ice in the south-western Kara Sea and northern Fram Strait). MSc thesis, University of Kiel.

Larssen B.B., Elverhoi A. \& Aagaard P. 1987. Study of particulate material in sea ice in the Fram Strait-a contribution to paleoclimate research. Polar Research 5 , 313-315.

Maslowski W. 2008. When will summer Arctic sea ice disappear? Paper presented at Sustainability Weeks 2008Symposium on Drastic Change in the Earth System during Global Warming, 24 June, Sapporo, Japan. Hokkaido University Collection of Scholarly and Academic Papers.

Martin T. \& Martin T. 2006. Anomalies of sea-ice transports in the Arctic. Annals of Glaciology 44, 310-316.

Nghiem S.V., Rigor I.G., Perovich D.K., Clemente-Colón P., Weatherly J.W. \& Neumann G. 2007. Rapid reduction of Arctic perennial sea ice. Geophysical Research Letters 34, L19504, doi: 10.1029/2007GL031138.

Nies H., Harms I.H., Karcher M.J., Dethleff D., Bahe C., Kleine E., Loewe P., Oberhuber J.M., Kuhlmann G., Matishov D., Stepanov A. \& Vasiliev O.F. 1998. Anthropogenic radioactivity in the Arctic Ocean-results of a joint project. German Journal of Hydrography 50, 313-343.

Nürnberg D., Wollenburg I., Dethleff D., Eicken H., Kassens H., Letzig T., Reimnitz E. \& Thiede J. 1994. Sediments in Arctic sea ice-entrainment, transport and release. Marine Geology 119, 185-214.
Osterkamp T.E. \& Gosink J.P. 1984. Observations and analysis of sediment laden sea ice. In P.W. Barnes et al. (eds.): The Alaska Beaufort Sea: ecosystem and environment. Pp. 73-94. San Francisco: Academic Press.

Overland J., Turner J., Francis J., Gillett N., Marshall G. \& Tjernström M. 2008. The Arctic and Antarctic: two faces of climate change. EOS, Transactions of the American Geophysical Union 89, 177-184.

Parkinson C., Comiso J.C., Zwally H.J., Cavalieri D.J., Gloersen P. \& Campbell W.J. 1987. Arctic sea ice, 1973-1976: satellite passive-microwave observations. NASA Report, Special Publication SP-489.

Petschick R., Kuhn G. \& Gingele F.X. 1996. Clay mineral distribution in surface sediments of the South Atlantic: sources, transport, and relation to oceanography. Marine Geology 130, 203-229.

Pfirman S., Colony R., Nürnberg D., Eicken H. \& Rigor I. 1997. Reconstructing the origin and trajectory of drifting Arctic sea-ice. Journal of Geophysical Research-Oceans 102, 12 575-12 586.

Pfirman S., Haxby W.F., Colony R. \& Rigor I. 2004. Variability in Arctic sea ice drift. Geophysica/Research Letters 31, L16402, doi: 10.1029/2004GL020063.

Rachold V., Grigoriev M.N., Are F.E., Solomon S., Reimnitz E., Kassens H. \& Antonov M. 2000. Coastal erosion vs riverine sediment discharge in the Arctic shelf seas. International Journal of Earth Sciences 89, 450-460.

Reimnitz E., Marincovich Jr. L., McCormick M. \& Briggs W.M. 1992. Suspension freezing of bottom sediment and biota in the Northwest Passage and implications for Arctic Ocean sedimentation. Canadian Journal of Earth Sciences 29, 693-703.

Reimnitz E., McCormick M., Bischof J. \& Darby D.A. 1998. Comparing sea-ice sediment load with Beaufort Sea shelf deposits: is entrainment selective? Journal of Sedimentary Research 68, 777-787.

Reimnitz E., McCormick M., McDougall K. \& Brouwers E. 1993. Sediment export by ice rafting from a coastal polynaya, Arctic Alska, U.S.A. Arctic and Alpine Research 25, 83-98.

Rigor I. \& Colony R. 1997. Sea-ice production and transport of pollutants in the Laptev Sea, 1979-1993. Science of the Total Environment 202, 89-110.

Rothrock D.A. \& Zhang J. 2005. Arctic Ocean sea ice volume: what explains its recent depletion? Journal of Geophysical Research-Oceans 110, C01002, doi: 10.1029/ 2004JC002282.

Schauer U. (ed.) 2000. The expedition ARKTIS XV/3 of the Research Vessel "Polarstern" in 1999. Reports on Polar Research 350. Bremerhaven: Alfred Wegener Institute for Polar and Marine Research.

Sherwood C.R. 2000. Numerical model of frazil ice and suspended sediment concentrations and formation of sediment laden ice in the Kara Sea. Journal of Geophysical Research-Oceans 105, 14 061-14080.

Smedsrud L.H. 2003. Formation of turbid ice during autumn freeze-up in the Kara Sea. Polar Research 22, 267-286. 
Stein R. \& Fahl K. (eds.) 1997. Scientific cruise report of the Arctic expedition ARK-XIII/2 of RV "Polarstern" in 1997. Reports on Polar Research 255. Bremerhaven: Alfred Wegener Institute for Polar and Marine Research.

Stierle A.P. \& Eicken H. 2002. Sediment inclusions in Alaskan coastal sea ice: spatial distribution, interannual variability, and entrainment requirements. Arctic, Antarctic, and Alpine Research 34, 465-476.

Stroeve J.C., Serreze M.C., Fetterer F., Arbetter T., Meier W., Maslanik J. \& Knowles K. 2005. Tracking the Arctic's shrinking ice cover: another extreme September minimum in 2004. Geophysical Research Letters 32, L04501, doi: 10.1029/2004GL021810.

Stroeve L., Holland M.M., Meier W., Scambos T. \& Serreze M. 2007. Arctic sea ice decline: faster than forecast. Geophysical Research Letters 34, L09501, doi: 10.1029/ 2007 GL029703.

Tucker M. 1996. Methoden der Sedimentologie. (Methods in sedimentology.) Stuttgart: Ferdinand Enke Verlag.

Vinje T. 2001. Fram Strait ice fluxes and atmospheric circulation: 1950-2000. Journal of Climate 14, 3508-3517.
Vinje T., Nordlund N. \& Kvambekk A. 1998. Monitoring ice thickness in Fram Strait. Journal of Geophysical Research-Oceans 103, $10437-10449$.

Wahsner M., Müller C., Stein R., Ivanov G., Levitan M., Shelekova E. \& Tarasov G. 1999. Clay mineral distribution in surface sediments of the Eurasian Arctic Ocean and continental margin as indicator for source areas and transport pathways - a synthesis. Boreas 28, 215-233.

Winsor P. \& Björk G. 2000. Polynya activity in the Arctic Ocean from 1958 to 1997. Journal of Geophysical Research-Oceans 10, 8789-8803.

Wollenburg I. 1993. Sediment transport by Arctic sea ice: the recent load of lithogenic and biogenic material. Reports on Polar Research 127. Bremerhaven: Alfred Wegener Institute for Polar and Marine Research.

Zakharov V.F. 1966. The role of flaw leads off the edge of fast ice in the hydrological and ice regime of the Laptev Sea. Oceanology 6, 815-821. 